\title{
PARACOCCIDIOIDOMYCOSIS: ADVANCES AND UNMET NEEDS 100 YEARS AFTER ITS INITIAL DESCRIPTION BY LUTZ
}

Initially described by Adolfo Lutz in 1908, paracoccidioiodomycosis (PCM) is considered to be the most prevalent endemic systemic mycosis in Brazil and other Latin American countries. Based on data generated by epidemiological surveys employing intradermal tests for paracoccidioidin, the prevalence of Paracoccidioides brasiliensis infection in these endemic areas may be as high as $50 \%$ to $75 \%$ among the adult population, and almost 10 million people may have been infected by this pathogen $(1,21)$.

One hundred years after the original description of PCM, we may celebrate several instances of substantial progress in characterizing $P$. brasiliensis. These advances include the complete sequencing of its genome, the evaluation of molecular factors that trigger the transition from hyphal to yeast form, the determination of the most relevant virulence factors as well as the importance of the glycoprotein gp43 in terms of fungal pathogenesis and mediating host-immune response. In addition, several well-conducted studies have consistently characterized the cell-mediated immune mechanisms needed to contain P. brasiliensis infection. In this regard, Type 1 (Th1) response, with high levels of IFN- $\gamma$ and IL-2, has been related to immunity in animal and human models of the disease. On the other hand, susceptibility is linked to Type 2 (Th2) response, and production of IL-4, IL-5, IL-10 and TGF- $\beta(2,4,8,11,13,14$, $17,19)$.

In terms of diagnosis, the advances are also remarkable since today we have available both several sensitive and specific methods for detecting anti-P. brasiliensis antibodies and ELISA assays for detecting specific antigens of the fungus in different biological fluids. Different polymerase chain reaction-based methods exist not only for identifying PCM, but also for genotyping $P$. brasiliensis isolates $(4,7,9,12,16$, 21).

Antifungal treatment of patients with paracoccidioidomycosis is still controversial. The few studies available on antifungal treatment of PCM enrolled a limited number of patients, and were neither randomized nor statistically robust $(18,21)$. Thus, they did 
not permit consistent conclusions about comparative efficacy analysis. Considering the limited data generated by well-conducted clinical trials in PCM, most guidelines for treating patients with this fungal infection are strongly based on expert opinions (18).

Long-term therapy consisting mostly of itraconazole or the combination of trimethoprim and sulfamethoxazole is usually required to achieve good clinical response and avoid relapses that are clearly correlated with drug toxicity, high costs and abandonment of treatment by patients $(1,18,21)$. Recently, Queiroz-Telles et al. (15) demonstrated that although voriconazole is a safe alternative therapy for patients with $\mathrm{PCM}$, it still requires long periods of treatment.

Besides the long periods of antifungal therapy required by these patients, relapses remain a significant problem in clinics. The non-responsive severely ill patients represent an unsolved problem for the conventional therapeutic approach. Patients who receive antifungal therapy but do not develop a stable Th1 response against the fungal pathogen are more prone to relapse $(1,18,21)$.

Despite all scientific progress towards the characterization of $P$. brasiliensis and its pathogenesis in animal and human models, as well as the standardization of sensitive laboratory tests to diagnose PCM, this endemic mycosis remains a major cause of disability and death among rural young adult workers during their most productive years of life. This phenomenon is partially related to the social and economic status of the target population for this disease, mostly represented by rural workers with low incomes and limited access to a public or private health system. It is important to mention that limited economic resources may impair the host response to fungal infection and hinder the early detection of infected patients by the health care system. Consequently, at the time most patients are diagnosed with fungal infection, they are already severely ill with multiple organs compromised by the disease (21).

There is a consensus that respiratory failure and adrenal insufficiency are two of the most commonly reported sequelae among adult patients who develop PCM. A study carried out by Tobón et al. (20) documented lung sequelae among 47 adult patients with PCM treated with itraconazole. Fibrosis was observed in $31.8 \%$ of the patients at diagnosis and had not cleared at the end of the observation period in any of these patients. After starting treatment, some of the others patients also developed fibrosis and by the end of the follow-up period the disease was detected in $53.2 \%$ of patients 
overall. Adrenal dysfunction secondary to PCM may be detected in $10 \%$ to $44 \%$ of patients evaluated by different functional tests, including evaluation of cortisol synthesis by infusion of Cortrosyn ${ }^{\circledR}$ (exogenous adrenocorticotropic hormone). Symptomatic adrenal dysfunction has been reported in $3 \%$ to $6 \%$ of patients (5).

Based on data obtained from the Brazilian Health Ministry's Mortality Information System, a total of 3,181 PCM deaths were reported in Brazil between 1980 and 1995 , corresponding to a mortality rate of 1.45 deaths per million inhabitants (6). A recent publication using the same mentioned death registry data attempted to exclusively evaluate the mortality rate of PCM reported in the state of Parana, an area highly endemic for this fungal infection, in which the average PCM mortality rate was 3.48 per million inhabitants, ranking this fungal infection as the fifth most common cause of death among all chronic infections with high prevalence in that particular region (3).

In conclusion, it is possible to suggest that the scientific community may celebrate several relevant contributions obtained in the study of this pathogen's biology, mechanisms of infection and host-response. New sensitive and specific diagnostic tools were developed but, unfortunately, they were not incorporated into the routine of most public medical centers due to cost issues and lack of human resources trained in medical mycology. New efforts are necessary to enable early diagnosis of paracoccidioidomycosis and to develop alternative therapeutic strategies against the fungus to improve patient compliance and final efficiency of the regimens (21). Recently, Travassos and colleagues (21) have demonstrated that a peptide-based vaccine may induce a Th1 response in Balb/c mice infected by $P$. brasiliensis, resulting in a significant reduction in the fungal load. This finding suggests that in the future we may have patients treated by immune stimulation with peptide vaccine as an adjuvant to antifungal drugs in order to shorten the treatment period of and decrease the number of relapses and sequels $(10,21)$. 
A. L. Colombo PARACOCCIDIOIDOMYCOSIS: ADVANCES AND UNMET NEEDS 100 YEARS AFTER ITS INITIAL DESCRIPTION BY LUTZ. J. Venom. Anim. Toxins incl. Trop. Dis., 2008, 14, 3, p. 390

\section{REFERENCES}

1 BERNAD G., FRANCO M. Paracoccidioidomycosis. In: MERZ WG., HAY RJ. Eds. Medical mycology: Topley \& Wilson's microbiology and microbial infections. 10.ed. Washington: ASM Press, 2005, 541-59.

2 BERNARD G., ROMANO CC., CACERE CR., JUVENALE M., MENDES-GIANNINI MJS., DUARTE AJS. Imbalance of IL-2, IFN- $y$ and IL-10 secretion in the immunosuppression associated with human paracoccidioidomycosis. Cytokine, 2001,13, 248-52.

3 BITTENCOURT JIM., OLIVEIRA RM., COUTINHO ZF. Paracoccidioidomycosis mortality in the state of Paraná, Brasil, 1980/1998. Cad. Saúde Pública, 2005, 21, 1856-64.

4 CAMARGO ZP., FRANCO MF. Current knowledge on pathogenesis and immunodiagnosis of paracoccidioidomycosis. Rev. Iberoam. Micol., 2000, 17, 41-8. 5 COLOMBO AL., FAIÇAL S., KATER CE. Systemic evaluation of the adrenocortical function in patients with paracoccidioidomycosis. Mycopathologia, 1994, 127, 89-93, 6 COUTINHO ZF., SILVA D., LAZERA M., PETRI V., OLIVEIRA RM., SABROZA PC., WANKE B. Paracoccidioidomycosis mortality in Brazil (1980-1995). Cad. Saúde Pública, 2002, 18, 1441-54.

7 DA SILVA SH., GROSSO DM., LOPES JD., COLOMBO AL., BLOTTA MH., QUEIROZ-TELLES F., de CAMARGO ZP. Detection of Paracoccidioides brasiliensis gp70 circulating antigen and follow-up of patients undergoing antimycotic therapy. J. Clin. Microbiol., 2004, 42, 2419-24.

8 FELIPE MS., TORRES FA., MARANHÃO AQ., SILVA-PEREIRA I., POÇASFONSECA MJ., CAMPOS EG., MORAES LM., ARRAES FB., CARVALHO MJ., ANDRADE RV., NICOLA AM., TEIXEIRA MM., JESUÍNO RS., PEREIRA M., SOARES CM., BRÍGIDO MM. Functional genome of the human pathogenic fungus Paracoccidioides brasiliensis. FEMS Immunol. Med. Microbiol., 2005, 45, 369-81.

9 GOMES GM., CISALPINO PS., TABORDA CP., de CAMARGO ZP. PCR for diagnosis of paracoccidioidomycosis. J. Clin. Microbiol., 2000, 38, 3478-80.

10 IWAI LK., YOSHIDA M., SADAHIRO A., DA SILVA WR., MARIN ML., GOLDBERG AC., JULIANO MA., JULIANO L., SHIKANAI-YASUDA MA., KALIL J., CUNHA-NETO E., TRAVASSOS LR. T-Cell recognition of Paracoccidioides brasiliensis gp43-derived peptides in patients with paracoccidioidomycosis and healthy individuals. Clin. Vaccine Immunol., 2007,14, 474-6. 
11 MAMONI RL., BLOTTA MH. Kinetics of cytokines and chemokines gene expression distinguishes Paracoccidioides brasiliensis infection from disease. Cytokine, 2005, 32, 20-9.

12 MATUTE DR., SEPULVEDA VE., QUESADA LM., GOLDMAN GH., TAYLOR JW., RESTREPO A., McEWEN JG. Microsatellite analysis of three phylogenetic species of Paracoccidioides brasiliensis. J. Clin. Microbiol., 2006, 44, 2153-7.

13 MORAIS FV., BARROS TF., FUKADA MK., CISALPINO OS., PUCCIA R. Polymorphism in the gene coding for the immunodominant antigen gp43 from the pathogenic fungus Paracoccidioides brasiliensis. J. Clin. Microbiol., 2000, 38, 3960-6. 14 PERAÇOLI MT., KUROKAWA CS., CALVI SA., MENDES RP., PEREIRA PC., MARQUES SA., SOARES AM. Production of pro- and anti-inflammatory cytokines by monocytes from patients with paracoccidioidomycosis. Microbes Infect., 2003, 5, 413-8.

15 QUEIROZ-TELLES F., GOLDANI LZ., SCHLAMM HT., GOODRICH JM., ESPINEL-INGROFF A., SHIKANAI-YASUDA MA. An open-label comparative pilot study of oral voriconazole and itraconazole for long-term treatment of paracoccidioidomycosis. Clin. Infect. Dis., 2007, 45, 1462-9.

16 SAN-BLAS G., NIÑO-VEGA G., BARRETO L., HEBELER-BARBOSA F., BAGAGLI E., BRICEÑO R., MENDES RP. Primers for clinical detection of Paracoccidioides brasiliensis. J. Clin. Microbiol., 2005, 43, 4255-7.

17 SAN-BLAS G., NIÑO-VEGA G., ITURRIAGA T. Paracoccidioides brasiliensis and paracoccidioidomycosis: molecular approaches to morphogenesis, diagnosis, epidemiology, taxonomy and genetics. Med. Mycol., 2002, 40, 225-42.

18 SHIKANAI-YASUDA MA., QUEIROZ-TELLES F., MENDES RP., COLOMBO AL., MORETTI ML., GRUPO DE CONSULTORES DO CONSENSO EM PARACOCCIDIOIDOMICOSE. Guidelines in paracoccidioidomycosis. Rev. Soc. Bras. Med. Trop., 2006, 39, 297-310.

19 TABORDA CP., JULIANO MA., PUCCIA R., FRANCO M., TRAVASSOS LR. Mapping of the T-cell epitope in the major 43-Kilodalton glycoprotein of Paracoccidioides brasiliensis which induces a Th1 response protective against fungal infection in Balb/c mice. Infect. Immun., 1998, 66, 786-93. 
20 TOBÓN AM., AGUDELO CA., OSORIO ML., ALVAREZ DL., ARANGO M., CANO LE., RESTREPO A. Residual pulmonary abnormalities in adult patients with chronic paracoccidioidomycosis: prolonged follow-up after itraconazole therapy. Clin. Infect. Dis., 2003, 37, 898-904.

21 TRAVASSOS LR., TABORDA CP., COLOMBO AL. Treatment options for paracoccidioidomycosis and new strategies investigated. Expert Rev. Anti. Infect. Ther., 2008, 6, 251-62.

\section{CORRESPONDENCE TO:}

ARNALDO LOPES COLOMBO, Disciplina de Infectologia, Departamento de Medicina da Universidade Federal de São Paulo, Rua Botucatu, 740, Vila Clementino, 04023-062, São Paulo, SP, Brasil. Phone: +55 115082 4100. Email: colomboal@terra.com.br. 